\title{
The Role of Leadership in Academic Services
}

\author{
Jetty Erna Hilda Mokat* \\ State Administration Study Program \\ Faculty of Social Sciences \\ Universitas Negeri Manado \\ Manado, Indonesia \\ jettymokat@unima.ac.id
}

\begin{abstract}
Various efforts have been made to provide quality academic services, but in reality have not been able to answer the demands of change and the needs of service recipients, so that they still continue to raise their main complaints from students. Implementation of quality academic services is largely determined by leadership. This study aims to describe the role of leadership in the implementation of academic services at the Faculty of Social Sciences, Manado State University. Using descriptive qualitative methods, with data collection techniques through observation and in-depth interviews. Data analysis uses interactive model analysis. The results showed that the role of leadership in academic services as a director, agent of change, communicator and deputy / spokesperson was not optimal. Especially in the function of the leader as a director and agent of change. Leader as director namely; Academic administrative services are carried out based on the direction of the leadership, without making the SOP as a guide; Academic administration has not provided SOP as a basis / measure to act so as not to deviate from the stipulated provisions. The function of a leader as an agent of change, namely the leader lacks the readiness and strong commitment to make changes based on the needs and demands of the situation, in an effort to improve the quality of character learning, superior and competitive, which is reflected in the lack of adequate learning facilities and tools; the leadership paid less attention in structuring academic facilities and infrastructure.
\end{abstract}

Keywords: Role of Leadership, Public Services, Academic Services.

\section{INTRODUCTION}

Higher Education is a place for the development of science and technology for the campus community to develop their potential to produce quality graduates, competitive, characterized, superior, competitive, and able to innovate in various fields. To realize quality education management and academic services is not an easy thing to do, because it requires integrity, commitment and good cooperation from all parties (leaders, lecturers, employees, and students). Education is one of the important aspects in improving the quality of human life. Therefore it is very reasonable if universities are required to be able to provide academic services according to the demands of the needs of students as users of educational services in a professional, quality and maximum way.

Excellent, quality and professional service if it is in line with expectations, easy, and guaranteed quality, otherwise unsatisfactory services will be left behind. Those who deliver poor services at high prices are gradually eliminated, while those who deliver quality services at reasonable prices are larger. Osborne and Gaebler, Everyone has the right to seek satisfactory services according to their size as a guarantee of satisfaction [1]. Although the reality is that not all officers in higher education institutions carry out their duties as expected, because there are those who do not understand their position as public servants and the philosophical meaning of service.

Implementation of maximum academic management and services by leaders and leadership. Expected leadership is leadership that has high credibility and integrity coupled with a struggle to build commitment, be able to be an agent of change, be responsive to needs, and be able to innovate towards improving academic service performance. Innovation for educational institutions has a very important meaning for the development of science and technology. University leaders and leadership play an important role to make improvements and changes in the organization, being able to be a pioneer in improving academic service performance, because making changes to academic service improvement is closely related to employee performance. Once the importance of change in an organization, then Ali Farazmand stressed: "Innovation is a key to sound governance, and innovation in policy and administration is central to sound governance as well. Without innovations, governance falls into decay and in effectiveness, loses capacity to govern, and becomes a target of critism and failure. Sound governance demands continuous innovation in policy and governance processes, systems and values systems "[2]. Innovation is a must and a key 
factor for improving service quality that is fast, precise, simple, certain, competitive, and quality. Without innovation causes ineffectiveness and results in organizational failure.

Higher Education runs academic services through the "Tri Dharma Perguruan Tinggi" (Education / Teaching, Research, and Community Service). To realize this, we need a leader who can be relied on, has a spirit of service for the implementation of the vision and mission of the college. The success of the leader appears in his leadership. Leadership is the influencing process of leaders and followers to achieve organizational objectives through change [3]. There are five key elements of leadership, namely leaders, followers, influence, organizational goals and change. Stogdill sees leadership as "the process (act) of influencing the activities of an organized group in its efforts towards goal setting and goal achievement" [4]. So leadership as a process influences organized groups to achieve goals. Meanwhile, according to Yukl "leadership is related to the deliberate process of someone to emphasize their strong influence on others to guide, structure, facilitate activities and relationships within groups or organizations" [5]. Yulk explained that the ability to influence a leader through the process of providing guidance and direction with the intention of creating a good relationship in an effort to achieve organizational goals.

A leader's responsibility is not just carrying out routine work, but how to make the organization better. Mc Gannon and Eko, emphasized that "Leadership is action, not position" [6]. Leaders may be able to achieve what is expected, but not effective because they are less able to act to make meaningful changes. As leaders need to know the needs of subordinates to help leaders motivate and influence subordinates to be willing to work together to achieve goals. According to Max DePree that leaders must take a role in developing, expressing, and defending civility and values. In a civilized institution or corporation, we see good manners, respect for persons, an understanding of "good goods," and an appreciation of the way in which we serve each other [7]. Leaders in this case must play a role in carrying out their functions in order to provide more value to the subordinates, fight for their hopes for the common good, so that in the end they are able to pass on the spirit that gives birth to the next generation of leaders who are strong and of character.

A leader's responsibility is not just carrying out routine work, but how to make the organization better. Mc Gannon and Eko, emphasized that "Leadership is action, not position" [6]. Leaders may be able to achieve what is expected, but not effective because they are less able to act to make meaningful changes. As leaders need to know the needs of subordinates to help leaders motivate and influence subordinates to be willing to work together to achieve goals. According to Max DePree that leaders must take a role in developing, expressing, and defending civility and values. In a civilized institution or corporation, we see good manners, respect for persons, an understanding of "good goods," and an appreciation of the way in which we serve each other [7]. Leaders in this case must play a role in carrying out their functions in order to provide more value to the subordinates, fight for their hopes for the common good, so that in the end they are able to pass on the spirit that gives birth to the next generation of leaders who are strong and of character.

Without leadership, an organization will be weak because management activities will be passive. Leaders in each work unit of Manado State University including the Faculty of Social Sciences continue to make efforts to make quality academic services, but the reality has not been able to answer the demands of change and needs so that it raises complaints from students and lecturers. Complaints related to academic administrative services are not satisfactory, slow, lack of adequate learning facilities and infrastructure (LCD, lighting, study rooms), not on time teaching, and lecture schedules are not consistent. This study describes the role of leadership in realizing academic services and obstacles in academic services at the Faculty of Social Sciences, Manado State University (Unima).

\section{RESEARCH METHODS}

This research was conducted at the Faculty of Social Sciences, Manado State University, which aims to describe the role of leadership in academic services. Using qualitative research, with a case study approach. Sources of research data include primary and secondary data sources. Primary data sources were obtained from informants through interviews (Head of Section, Head of Subdivision, Staff, Lecturers and Students). Secondary data obtained through the study of documentation through written materials related to the focus of the problem. The collected data is checked by triangulating. Data analysis techniques used are qualitative descriptive analysis techniques, with interactive models, including: data reduction, data presentation and conclusion drawing [13].

\section{RESULTS AND DISCUSSION}

Many arguments related to good, effective and quality services, and how an organization can achieve maximum goals. Everything is closely related to human factors (leaders, who are led). Leaders with various characteristics show the image of the leaders themselves. 


\section{The role of the leader in Academic Services}

The role can be interpreted as an attitude or behavior related to the abilities and skills expected of a person in his capacity as a leader. "The role as behavior that is regulated and expected from someone in a certain position" [8]. Basically an organization leader is a person who has a role in regulating the behavior of people who are led so that it becomes effective. Effective leaders are leaders who have the ability to provide guidance, motivation and direction to subordinates / who are led so that organizational goals can be achieved as expected.

Leaders become the spearhead for the implementation of services in the organization and even key actors for the success of the organization. Public Service Law No. 25/2009, requires leaders as public servants to be able to provide the best service [14] through their duties and functions. The perceived inability of public leaders to carry out the mandate of the law is the cause of the bad image of the government as a leader in the eyes of the public, although it is believed there are still public leaders who show adequate and superior performance. This condition is a challenge for public leaders in finding solutions to change the negative image into positive according to the expectations of service users.AdministrasiAkademikFakultasIlmuSosialseb agaipenyelenggarapelayananakademikdari5

$\begin{array}{lllll}\text { jurusandan } & 3 & \text { program studidengan } 4\end{array}$ orangpengelola.Administrasiakademiksebagaisuatu sistemmengandungartibahwatiapbagian/sub bagian, jurusandan program studisalingberkaitan, mendukungdalammencapaivisidanmisifakultasdanp erguruantinggi.Untukpencapaianvisidanmisitersebu tperludidukungStandarOperasionalProsedur (SOP) yang

jelassebagaidasaroperasionaldanpedomanuntukme mastikanapakahsetiaptindakan, keputusan, proses pelaksanaansesuaiketentuan. Secarafaktual, berbagaitemuankelemahan

yangmengahambatpelayananakademik

FakultasIlmuSosial yang membutuhkanketerlibatanpemimpinmencarisolusip ermasalahan yang dihadapi.

\section{a. Leader as director}

The leader is very instrumental in determining the direction that must be taken by the organization to achieve its goals. Instruction / direction of tasks that must be done that requires cooperation between subordinates and leaders in order to achieve the expected goals. It becomes the authority of the leadership to direct subordinates to carry out their duties according to standards. Standards are measures of achievement towards a goal to be achieved [15]. The standard in question is the Standard Operating Procedure (SOP) as a reference for leaders to give direction to subordinates / employees carrying out tasks in achieving their goals. Basic directives as stated in the strategies that have been formulated by the organization.

Based on the results of research that academic administrative services are carried out based on leadership direction followed by providing motivation to employees. The direction of the leadership for academic administration services to be carried out according to procedures, but in reality in the academic administration section SOPs are not yet available as a basis for acting so as not to deviate from the stipulations and objectives. SOP is one form of written instructions that can help ease the burden of leadership tasks, and become a compass / measurement tool for the successful implementation of the task.

Once the importance of SOPs for the implementation of tasks in academic administrative services, the availability of SOPs is a must, because in the SOP the steps for completing tasks and work from beginning to end that facilitate the achievement of effective and efficient goals.

On the other hand, the expectation of the Faculty of Social Sciences as an institution producing superior human resources, being able to compete in the global market has not been realized as expected, because it is still faced with other academic issues such as: the availability of facilities and supporting infrastructure for learning inadequate (such as: LCD projectors, lighting, and lecture room limitations). The scarcity or inadequacy of learning support facilities greatly impacts the quality of learning.

\section{b. Leaders as agents of change}

Change is a process leading to better conditions, so it requires creativity, commitment and hard work from the leader. Because "leaders are not only policy makers but must be agents of change and actors in organizations" [15]. A leader is expected to be able to bring about new changes, and become a catalyst in his work environment. This means that a leader is the catalyst for change because it has a very decisive role in the change process. Change is a necessity in an organization, without making changes the organization will not develop.

Faculty leaders have tried to make positive changes to anticipate global developments by prioritizing changes, in accordance with the vision and mission of the faculty and translating into the reality of academic services, although not as expected. The leadership cooperates with partners (government and private institutions for apprenticeship and field practice), but also collaborates with lecturers with government agencies, village governments for research. But do not yet have a strong commitment to make changes in improving the quality of learning that is 
characterized, superior and competitive. This is reflected in the lack of adequate facilities and learning tools (the number of students is not in accordance with the availability of study space, the Projector LCD is very limited, and the internet network is less supportive / unstable).

\section{c. The leader as a communicator}

Communication is a very important aspect in an organization. With communication the goals to be achieved by the organization can be realized. "Communication is not only art but also knowledge that can be learned so that it can produce effective ways of communicating" [16]. Communication as a tool that helps the interaction process so that interaction can take place in harmony with each other. Communication can also help leaders and members of organizations carry out their activities to achieve goals. The relationship between leaders and subordinates can be established because of communication. Communication is an interaction between humans that can be used to send messages both verbally and non-verbally so that they can establish relationships with other people in life in the community.

The problem is how to deliver good information to members of the organization so that it is carried out effectively and on target ?. Pace and Faules (2001), Robbin and Judge (2007), Sunyoto and Burhanudin (2015) differentiate communication into four directions of flow, namely: downward communication; upward communication; horizontal communication; and cross-channel communication [17]. Communication can take place effectively if the channel used is right. Therefore communicators as sources of messages need to pay attention to four things: 1) skills in composing messages; 2) attitude in delivering messages; knowledge of the recipient of the message; and what response is expected from the recipient of the message [11].

The results showed that communication between leaders at the Faculty of Social Sciences and subordinates (teaching staff and education staff) can take place effectively. Mainly in discussing issues related to academic services, ranging from academic administrative services to lecture activities. The communication made is twoway communication (consultation), which is in the initial stages of determining the decision of the leader to make consideration by consulting with other leaders so as to obtain clear information, sufficient data as a reason for making decisions. In the next stage after the decision is carried out an evaluation is conducted through meetings of faculty leaders, departments and study programs. The results of the decision are submitted to the leadership of the University level. With good communication, consultation between leaders and subordinates can be established, so that the leadership process can take place effectively.

\section{d. Leader as Deputy / Spokesperson}

The leader is the person who represents the organization, so the leader must be able to become a negotiator and form a network with the organization's external environment. Being an effective leader, it is not enough just to have the ability and commitment if it is not implemented into the actions and activities of the organization, namely by continuing to stimulate the creativity of organizational members, providing incentives in the form of material or nonmaterial.

The leader as a spokesperson must have the ability to form a network of cooperation with parties outside educational organizations / institutions, as well as non-education. To build public trust and examine community expectations in order to create superior, competitive and competitive universities, the leadership of the Unima Faculty of Social Sciences set policies with various program activities involving students and lecturers, such as collaborating with various government / private agencies in the program Student work internships, taking part in student debate competitions between faculties and between universities. In addition, involving lecturers in national and international seminar activities (albeit in limited numbers), as an effort to improve the quality of lecturers and the realization of the vision and mission of the institution.

\section{Obstacles in Academic Administration Services.}

In principle, the implementation of academic services in the Faculty of Social Sciences has strived to match the policies and demands and expectations of students. But in its implementation it is still faced with various obstacles, so that it impacts the quality of academic services and student studies. Because: 1) the unavailability of standard operating procedures (SOP); 2) do not have a strong commitment to carry out academic services based on SOPs; 3) large amount and workload but not supported by adequate service facilities (computers, printers and internet networks).

Likewise, the activities in the learning process that do not fully support the vision and mission of the Faculty and the University to provide quality, character, superior and competitive academic services due to the unavailability of adequate learning facilities and devices, unstable internet networks, and lack of support for learning spaces.

\section{CONCLUSION}

Leadership in academic services as a director, change agent, communicator and deputy / spokesperson has been implemented, but not yet 
optimal, especially in the function of leadership as a director and agent of change. First, the steering function, namely academic administrative services carried out based on the direction of the leadership but does not make the SOP as a handle. The direction of the leadership for academic administration services to be carried out according to procedures, but in the academic administration section SOPs are not yet available as a basis for acting as a measure of acting so as not to deviate from the rules and objectives set. Leaders do not have the firmness and commitment to implement SOP.

Both functions as agents of change, lack the readiness and a strong commitment to make changes based on the needs and demands of the situation, in an effort to improve the quality of characterless, superior and competitive learning. Reflected in the lack of adequate facilities and learning tools; The leadership is less structured in terms of academic facilities and infrastructure.

\section{ACKNOWLEDGMENT}

The author would like to express her gratitude to the Heads of Faculty of Social Science, Manado State University for approving this study, and to the fellow Heads of Manado State University for providing the funding, so this study could be completed.

\section{REFERENCES}

[1] O. David and T. Gaebler, "General Series. Managing Bureaucracy ". Reinventing Government. Transforming Entrepreneurial Spirit into the Public Sector. Jakarta: Library of BinamanPressindo, 1999.

[2] Farazmand. Ali, "Sound Governance. Policy and Administrative Innovations, "London: Westport, Connecticul, 2004.
[3] Lussier. N. Robert, Christopher F. Achua. Leadership Theory Application. Skill Development. The USA. South-Western College Publishing

[4] S.Ralph, "Handbook of Leadership," A Survey of Theory and Research. London: Collier MacMillan Publishers, 1974.

[5] Y. Gary, "Leadership in Organizations," Ed. Fifth. Jakarta: PT Index, 2010.

[6] A. E. Maulana, "Leadership of Transformational Bureaucracy in Government Bureaucracy," Jakarta: MulticerdasPublising, 2012.

[7] Bass Reader-Jossey, "Non-Profit and Public Leadership," Edited by James L Perry, 2010.

[8] R. Veithzal, "Leadership and Organizational Behavior," Second Edition. Jakarta. PT RajaGrafindoPersada, 2004.

[9] Hicks, Herbert G. and G. Ray Gullet, "Organizational Theory and Behavior," Jakarta: Bina Aksara, 1987.

[10] R. Asmawi, "Leadership in Public Services," Jakarta: STIA LAN, 2011.

[11] S. P. Siagian, "Theory and Practice of Leadership". Jakarta: RinekaCipta, 2003.

[12] J. Mantiri, "The Role of Education in Creating Quality Human Resources in North Sulawesi Province," J. Civ. Educ. Kaji Media. Pancasila and Citizenship, 2019.

[13] M. Miles \& M. Huberman, "Qualitative Data Analysis. Resource Book About New Methods ", Tjetjep Translator RohendiRohidi. Jakarta: UI-Press, 2007

[14] Law Number 25 of 2009 concerning Public Services. Jakarta: AsaMandiri.

[15] Hayat, "Management of Public Services". Depok: RajaGrafindoPersada, 2017.

[16] T. Semuil, "To be a Great Effective Leader". Yogyakarta: Andi, 2012.

[17] S. Danang and Burhanudin, "Organizational Behavior Theory", Yogyakarta: CAPS (Center of Academic Publishing Service), 2015 